\title{
Drilling and Construction Data for the Waiohuli Exploratory Well (State Well 6-4421-01), Island of Maui, Hawaii
}

By Stephen B. Gingerich and David R. Sherrod

U.S. GEOLOGICAL SURVEY

Open-File Report 02-477

Prepared in cooperation with the

DEPARTMENT OF HAWAIIAN HOME LANDS

STATE OF HAWAII 


\section{U.S. DEPARTMENT OF THE INTERIOR \\ GALE A. NORTON, Secretary}

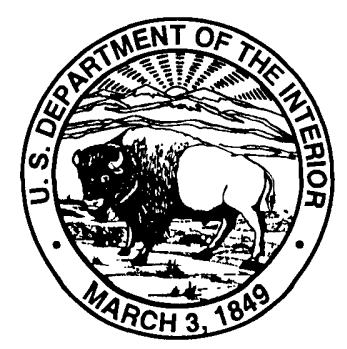

\section{U.S. GEOLOGICAL SURVEY}

Charles G. Groat, Director

The use of firm, trade, and brand names in this report is for identification purposes only and does not constitute endorsement by the U.S. Geological Survey.

For additional information write to:

District Chief

U.S. Geological Survey

677 Ala Moana Blvd., Suite 415

Honolulu, HI 96813
Copies of this report can be purchased from:

U.S. Geological Survey

Branch of Information Services

Box 25286

Denver, CO 80225-0286 


\title{
CONTENTS
}





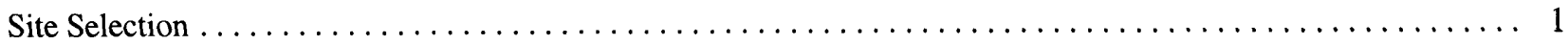

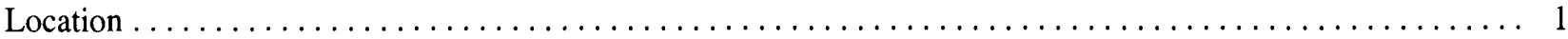

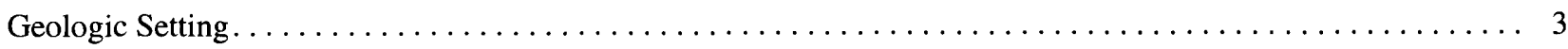

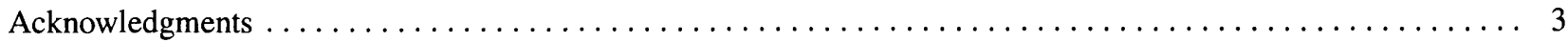

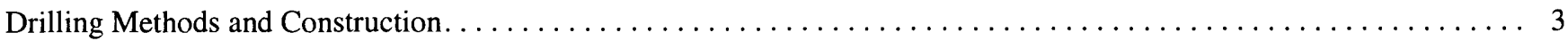

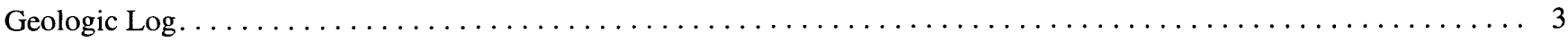

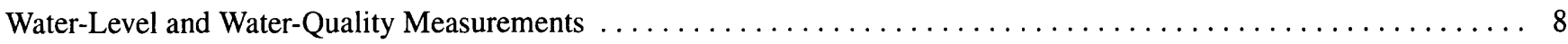

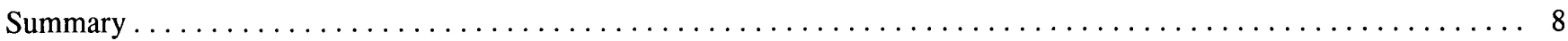

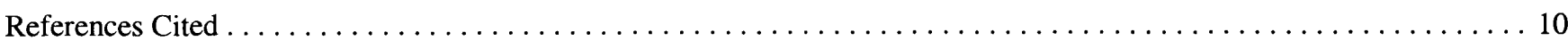

\section{FIGURES}

1-2. Maps showing:

1. Location of the Waiohuli exploratory well (State well 6-4421-01), Maui, Hawaii . . . . . . . . . . . . 2



3. Diagram showing construction details of the Waiohuli exploratory well (State well 6-4421-01),

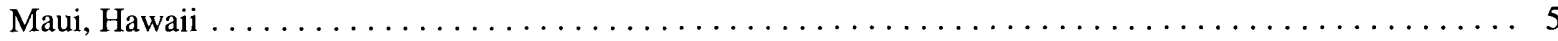

4. Geologic $\log$ for the Waiohuli exploratory well (State well 6-4421-01), Maui, Hawaii . . . . . . . . . . . . 6

\section{TABLES}

1. Location, altitude, and State number of the Waiohuli exploratory well, Maui, Hawaii. . . . . . . . . . . . 3

2. Lithologic descriptions of drill cuttings collected from Waiohuli exploratory well (State well 6-4421-01),

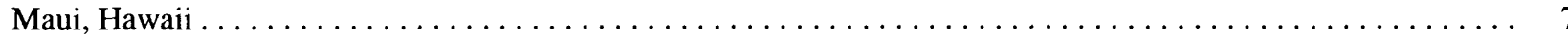

3. Chemical analysis of selected rock cuttings collected during drilling of the Waiohuli exploratory well

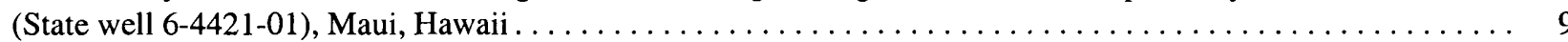

4. Water-level measurements from the Waiohuli exploratory well, Maui, Hawaii between September 2001 and August 2002 .

CONVERSION FACTORS, ABBREVIATIONS, AND VERTICAL DATUM

\begin{tabular}{rll}
\hline Multiply & By & To obtain \\
\hline inch (in.) & 2.54 & centimeter \\
foot $(\mathrm{ft})$ & 0.3048 & meter \\
cubic foot per minute $\left(\mathrm{ft}^{3} / \mathrm{min}\right)$ & 0.02832 & cubic meter per minute \\
gallon per minute $(\mathrm{gal} / \mathrm{min})$ & 3.785 & liter per minute \\
mile, statute $(\mathrm{mi})$ & 1.609 & kilometer \\
\hline
\end{tabular}

\begin{abstract}
Abbreviations
$\mu \mathrm{S} / \mathrm{cm}$, microsiemens per centimeter at 25 degrees Celsius $\mathrm{mg} / \mathrm{L}$, milligrams per liter
\end{abstract}

\section{Datums}

Vertical coordinate information is referenced relative to mean sea level.

Horizontal coordinate information is referenced to the North American Datum of 1983 (NAD 83). 


\title{
Drilling and Construction Data for the Waiohuli Exploratory Well (State Well 6-4421-01), Island of Maui, Hawaii
}

\author{
By Stephen B. Gingerich and David R. Sherrod
}

\begin{abstract}
The Waiohuli exploratory well, located on the western slope of Haleakala, Maui, Hawaii, was drilled in 2001 to investigate the hydrology and geology in an area where other well information was not available. The well was drilled from a ground altitude of about 1,864 feet and penetrated a 1,940-foot section of subaerial lava flows (consisting of basanite, hawaiite, and alkalic basalt) with interbedded tephra. Water levels measured in the well ranged from about 5 to 6 feet above sea level.
\end{abstract}

\section{INTRODUCTION}

The Waiohuli exploratory well was drilled during April to August 2001 by the U.S. Geological Survey (USGS) in cooperation with the State of Hawaii Department of Hawaiian Home Lands to explore the availability of ground water and the geology on the western slope of Haleakala (also known as East Maui Volcano) (fig. 1). The objectives for drilling the well include determining (1) the water-table altitude in the area, (2) the salinity of water in the aquifer at the well, and (3) the subsurface geology of the area. The Department of Hawaiian Home Lands considers the Waiohuli area a potential site for future ground-water development.

This report documents (1) the well location, (2) drilling and well-construction information from the drillers, (3) geologic descriptions of the rock cuttings brought to the surface during drilling, (4) available water-level information, and (5) chloride concentration, specific conductance, and temperature of water in the well.

\section{Site Selection}

The exploratory well was sited in an area where no wells had been drilled and no subsurface information was available and is at least $5 \mathrm{mi}$ from the nearest pumped wells. Site selection was also guided by (1) the need to have the well on public land for future access, (2) the need to have the well near a road for drilling equipment access, and (3) the need to avoid drilling near Puu O Kali because of the potential effects of drilling activity on threatened or endangered species and the possible geologic complications associated with the volcanic feature.

\section{Location}

The Waiohuli exploratory well is on ranchland leased from the State of Hawaii Department of Hawaiian Home Lands, about $1.7 \mathrm{mi}$ west and downhill from the Kula Highway (State Road 37) on the western flank of Haleakala (fig. 2). The well is about $2,000 \mathrm{ft}$ downslope from the downhill end of Laueie Road, a new subdivision road not yet shown on the topographic map. The well was assigned the well number 6-4421-01 by the State of Hawaii Commission on Water Resource Management using the State well-numbering system (table 1).

No perennial surface-water bodies lie within at least $4 \mathrm{mi}$ of the well. The nearest intermittent stream valley is Waiohuli Gulch, about $0.1 \mathrm{mi}$ south of the well. The well is about $5.4 \mathrm{mi}$ inland from the western coast of east Maui. 


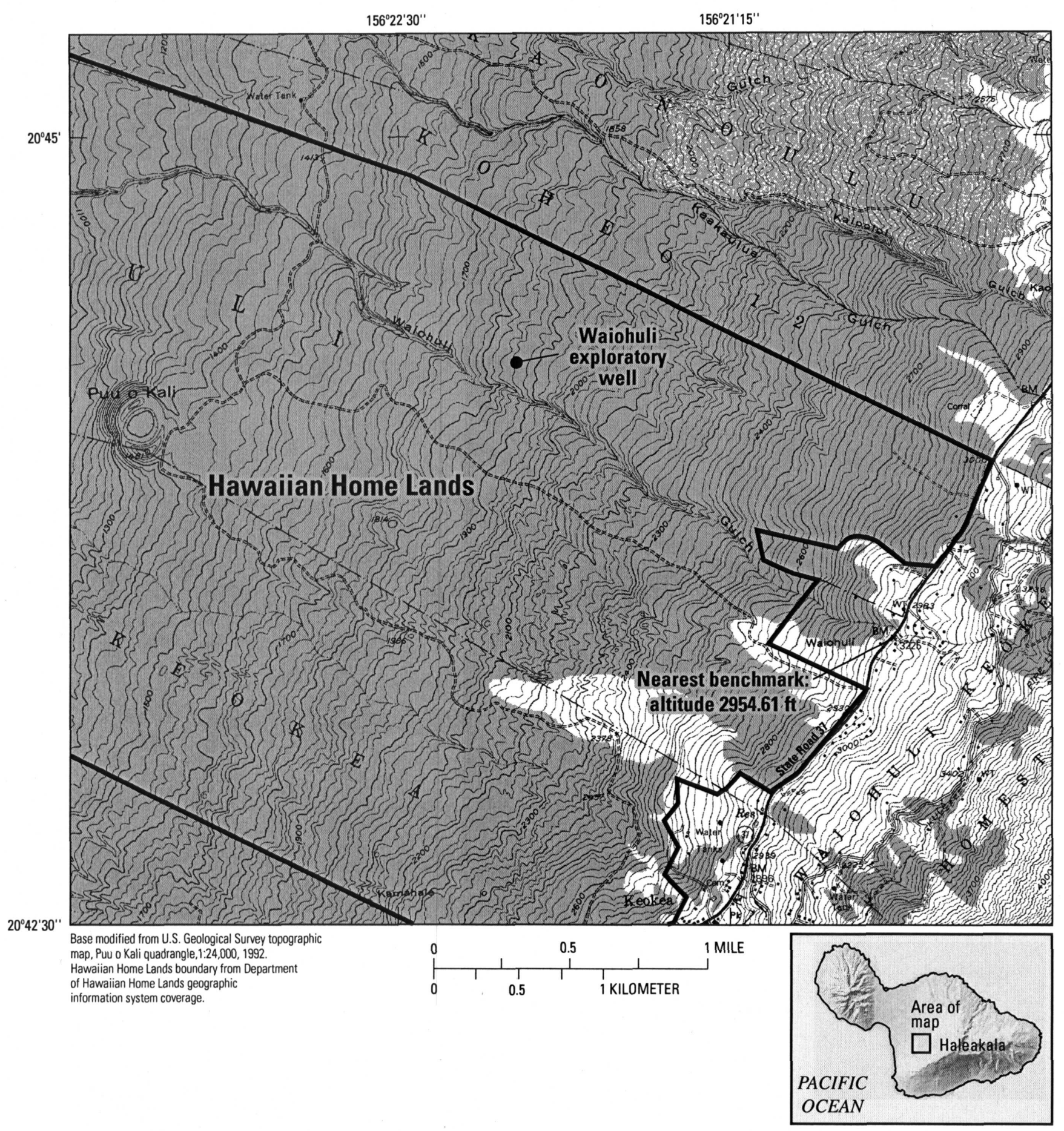

Figure 1. Location of the Waiohuli exploratory well (State well 6-4421-01), Maui, Hawaii. 
Table 1. Location, altitude, and State number of the Waiohuli exploratory well, Maui, Hawaii

[Vertical datum is mean sea level; latitude and longitude measured using GPS (global positioning system) and referenced to NAD83 datum]

\begin{tabular}{ll}
\hline Latitude & $20^{\circ} 44^{\prime} 07^{\prime \prime} \mathrm{N}$ \\
Longitude & $156^{\circ} 21^{\prime} 55^{\prime \prime} \mathrm{W}$ \\
$\begin{array}{l}\text { Ground altitude at brass plate in } \\
\text { concrete pad }\end{array}$ & $1,864.33 \mathrm{feet}$ \\
$\begin{array}{l}\text { Measuring-point altitude at top of } \\
\quad \text { 4-inch well casing }\end{array}$ & $1,867.56 \mathrm{feet}$ \\
$\begin{array}{l}\text { Distance and direction from Keokea } \\
\text { Distance and direction from nearest }\end{array}$ & $\begin{array}{c}2.2 \text { miles north- } \\
\text { northwest }\end{array}$ \\
$\quad$ shoreline & 5.4 miles east \\
State well number & $6-4421-01$ \\
\hline
\end{tabular}

\section{Geologic Setting}

The Waiohuli exploratory well is located on the western flank of Haleakala, a broad shield volcano that forms the eastern part of the island of Maui. Haleakala was built chiefly by thousands of pahoehoe and aa lava flows erupted during the past 2 million years, the last 1 million years of which the flows erupted above sea level (Stearns and Macdonald, 1942). Consequently the drill hole penetrates almost entirely through lava flows.

Additionally, tephra deposits are interbedded among the lava flows. Though generally thin, these deposits are as thick as 6 to $9 \mathrm{ft}$.

Two major stratigraphic units, the Kula Volcanics and the Hana Volcanics, are mapped at the surface on Haleakala's west flank (Stearns and Macdonald, 1942) (fig. 2). The Kula Volcanics comprises chiefly basanite and hawaiite lava in flows that were emplaced as aa. Pahoehoe is sparse. The Kula Volcanics unit represents the alkalic-cap stage of Hawaiian volcano evolution (Langenheim and Clague, 1987). Hana Volcanics is not found at the drill site.

A third stratigraphic unit, the Honomanu Basalt, is inferred to underlie the Kula Volcanics. Though not exposed on the volcano's west flank, the Honomanu Basalt is found in deep canyons on the north and possibly the southeast side (Stearns and Macdonald, 1942). The Honomanu Basalt, containing both pahoehoe and aa lava flows, was emplaced as Haleakala progressed from its shield-building to alkalic-cap stage (Langenheim and Clague, 1987).

\section{Acknowledgments}

The drilling and construction of the Waiohuli exploratory well was made possible with the cooperation and assistance of Darrell Yagodich, Carolyn Darr, and Daniel Ornellas of the Department of Hawaiian Home Lands and David Craddick of the Maui Department of Water Supply.

\section{DRILLING METHODS AND CONSTRUCTION}

The well was bored by rotary drilling with an 77/8-in.-diameter tungsten-carbide bit. Air and foam were injected down through the hollow drill stem and circulated back up the space between the stem and the well bore to remove water and cuttings from the hole. The Waiohuli exploratory well was drilled to a depth of $1,940 \mathrm{ft}$ from an altitude of about $1,864 \mathrm{ft}$.

A 1,924-ft solid steel casing with a 4-in. inner diameter was installed and the bottom $90 \mathrm{ft}$ was hand perforated to create a well screen. The altitude of a brass plate in a concrete pad surrounding the well is $1,864.33$ $\mathrm{ft}$ and the altitude of the measuring point notched in the top of the steel well casing is $1,867.56 \mathrm{ft}$. The well altitude was determined by leveling survey from a benchmark (National Geodetic Survey No. P23; alt. 2,954.61 $\mathrm{ft}$ ) on the east side of a bridge along State Road 37 (fig. 1). Construction details of the finished well are shown in figure 3. Kimo Akina was the head of the USGS drill crew for well construction.

\section{GEOLOGIC LOG}

The geologic log (fig. 4) of the Waiohuli exploratory well was compiled from cuttings brought to the surface by the air and foam circulated through the well bore. Samples were collected at 5-ft depth intervals, then rinsed and dried before being examined at lowpower magnification with a binocular microscope. Lithologic descriptions appear in table 2. The following terms refer to the percentage of phenocrysts found in the samples: slightly porphyritic, 1 to 3 percent; moderately porphyritic; 3 to 10 percent; highly porphyritic, 10 to 25 percent. 


\section{EXPLANATION}

SEDIMENTARY DEPOSITS (Holocene and Pleistocene)

\section{WEST MAUI VOLCANO}

Lahaina Volcanics (Pleistocene) Honolua Volcanics (Pleistocene) Wailuku Basalt (Pleistocene)

\section{EAKALA)}

VOLCANO

Hana Volcanics (Holocene and Pleistocene?)

Kipahulu Member (Pleistocene?)

Kula Volcanics (Pleistocene)

Honomanu Basalt (Pleistocene)
- CINDER, SPATTER,

AND PUMICE CONES

CONTACT

\section{APPROXIMATE}

CALDERA BOUNDARY

I"I!!"!" AXIS OF RIFT ZONE-

Approximately located

Base modified from U.S. Geological Survey

digital data, 1:24,000, 1983, Albers equal are

projection, standard parallels $20^{\circ} 39^{\prime} 30^{\prime \prime}$ and

$20^{\circ} 57^{\prime} 30^{\prime \prime}$, central meridian 156²0'15

WEST MAUI

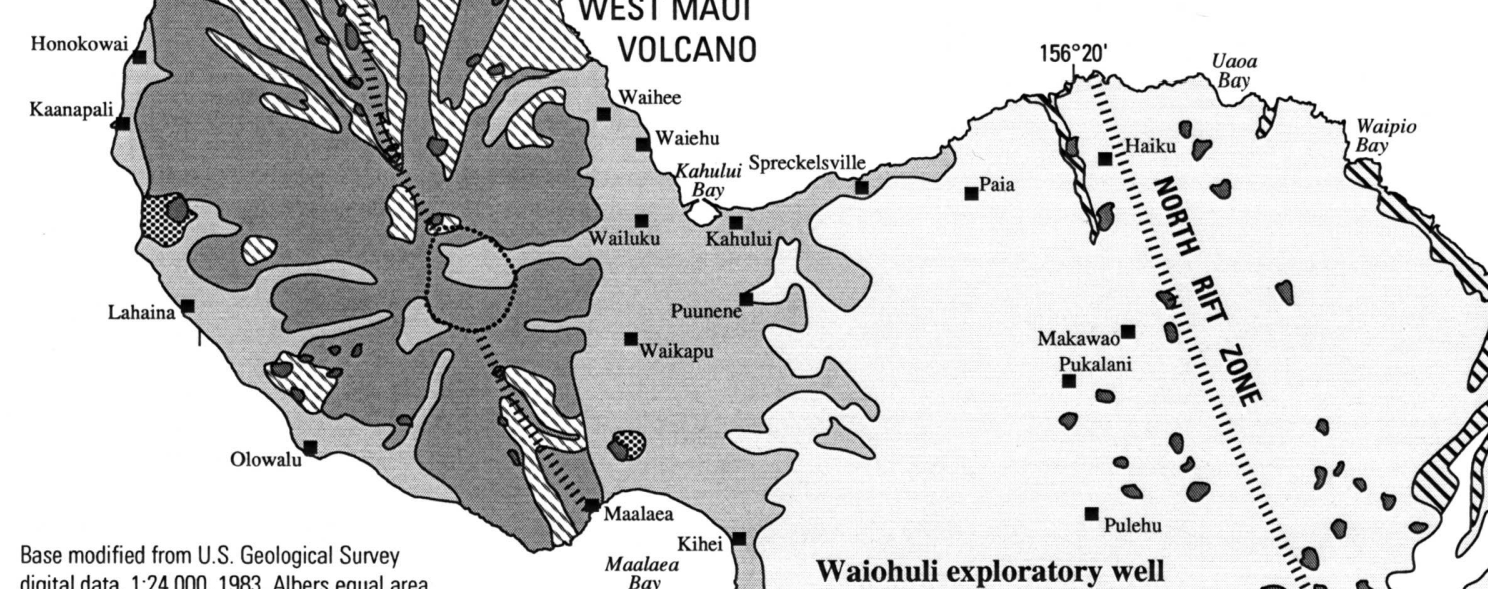

1. OKeanae

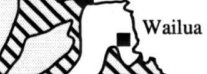

Nahik

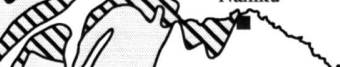

$\therefore 8$

Maala
Bay

Waiohuli exploratory well (State well 6-4421-01) 10 of g


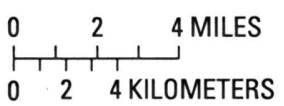

Figure 2. Generalized surficial geology, Maui, Hawaii (modified from Langenheim and Clague, 1987). 


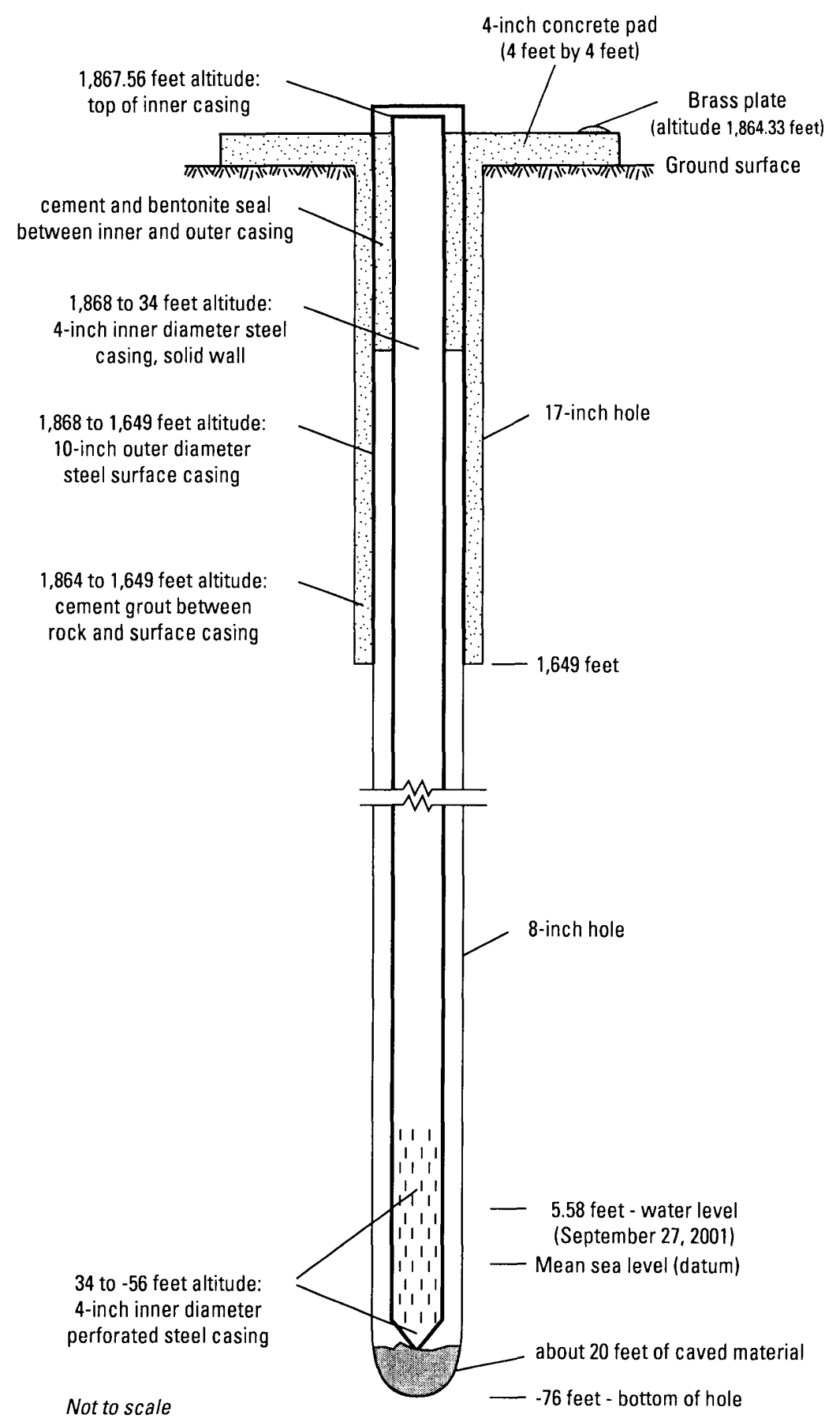

Figure 3. Diagram showing construction details of the Waiohuli exploratory well (State well 6-4421-01), Maui, Hawaii. 
INTERVAL SAMPLED FOR CHEMICAL ANALYSIS
ALTITUDE, IN

FEET ABOVE

MEAN SEA LEVEL

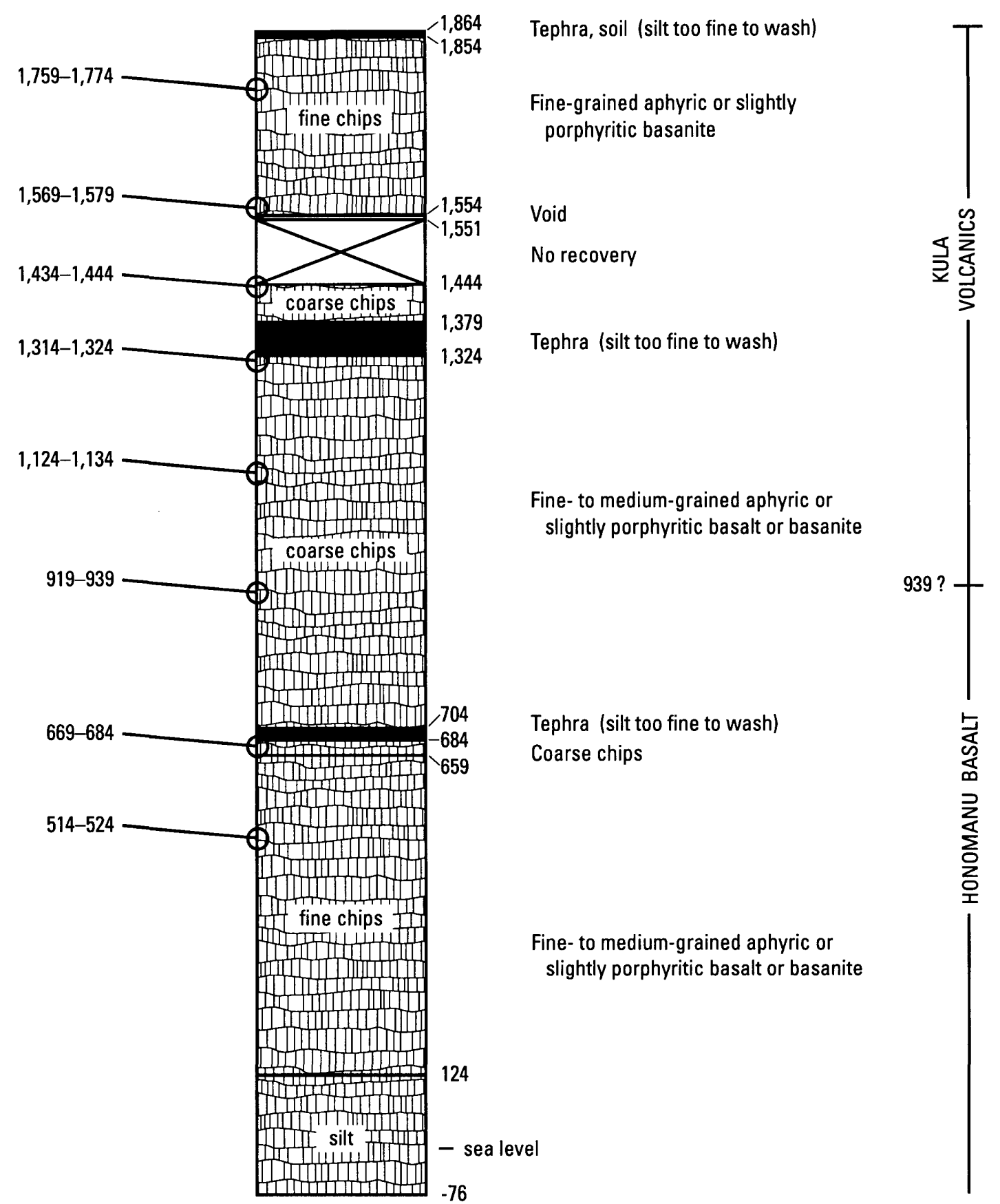

Figure 4. Geologic log for the Waiohuli exploratory well (State well 6-4421-01), Maui, Hawaii. 
Table 2. Lithologic descriptions of drill cuttings from Waiohuli exploratory well (State well 6-4421-01), Maui, Hawaii

[Datum is mean sea level; depth measured from 1,864 feet above sea level; slightly porphyritic, 1 to 3 percent phenocrysts; moderately porphyritic, 3 to 10 percent phenocrysts; highly porphyritic, 10 to 25 percent phenocrysts]

\begin{tabular}{|c|c|c|c|c|c|c|}
\hline \multicolumn{3}{|c|}{$\begin{array}{c}\text { Altitude } \\
\text { (feet) }\end{array}$} & \multicolumn{3}{|c|}{$\begin{array}{l}\text { Depth } \\
\text { (feet) }\end{array}$} & \multirow[t]{2}{*}{ Sample description ${ }^{1}$} \\
\hline 1,864 & to & 1,859 & 0 & to & 5 & \\
\hline 1,854 & to & 1,554 & 10 & to & 310 & dark-gray fresh aphyric to slightly porphyritic lava \\
\hline 1,554 & to & 1,444 & 310 & to & 420 & No recovery due to void between $1,551-\mathrm{ft}$ and $1,544-\mathrm{ft}$ altitude \\
\hline 1,444 & to & 1,384 & 420 & to & 480 & Medium-gray aphyric lava \\
\hline 1,384 & to & 1,379 & 480 & to & 485 & Light-brownish gray grit-size lava chips \\
\hline 1,379 & to & 1,324 & 485 & to & 540 & Light-brownish gray silt- to sand-size chips, probably weathered tephra \\
\hline 1,324 & to & 1,124 & 540 & to & 740 & Medium-gray aphyric lava; some chips with sparse small olivine \\
\hline 1,124 & to & 1,119 & 740 & to & 745 & Medium-gray lava; slightly olivine-bearing chips more abundant \\
\hline 1,119 & to & 1,114 & 745 & to & 750 & Medium-gray lava; slightly olivine-bearing chips more abundant \\
\hline 1,114 & to & 1,109 & 750 & to & 755 & $\begin{array}{l}\text { Medium-gray lava, several chips moderately to highly porphyritic with olivine and } \\
\text { clinopyroxene }\end{array}$ \\
\hline 1,109 & to & 1,104 & 755 & to & 760 & Medium gray lava, 70 percent of chips aphyric, 30 percent moderately to highly porphyritic \\
\hline 1,104 & to & 964 & 760 & to & 900 & $\begin{array}{l}\text { Chiefly medium-gray aphyric lava, } 20 \text { percent with olivine phenocrysts } 1 \text { to } 2 \mathrm{~mm} \text {; rarely } \\
\text { plagioclase- or clinopyroxene-bearing }\end{array}$ \\
\hline 964 & to & 954 & 900 & to & 910 & Medium-gray lava; 50 percent aphyric and 50 percent moderately plagioclase-phyric \\
\hline 954 & to & 944 & 910 & to & 920 & Chiefly medium-gray aphyric lava, 20 percent porphyritic lava \\
\hline 944 & to & 914 & 920 & to & 950 & Medium-gray lava, many chips moderately plagioclase-phyric, phenocrysts 1 to $2 \mathrm{~mm}$ \\
\hline 914 & to & 884 & 950 & to & 980 & Medium-gray lava; abundance of plagioclase-bearing chips diminishes \\
\hline 884 & to & 704 & 980 & to & 1,160 & $\begin{array}{l}\text { Chiefly medium-gray aphyric lava; } 10-20 \text { percent moderately olivine-phyric lava and only } \\
\text { scant plagioclase-phyric chips }\end{array}$ \\
\hline 704 & to & 684 & 1,160 & to & 1,180 & Medium-gray silt- and sand-size matter \\
\hline 684 & to & 584 & 1,180 & to & 1,280 & $\begin{array}{l}\text { Chiefly medium-gray aphyric lava; } 20 \text { to } 30 \text { percent moderately olivine-phyric lava with } \\
\text { scattered clinopyroxene phenocrysts }\end{array}$ \\
\hline 584 & to & 524 & 1,280 & to & 1,340 & $\begin{array}{l}\text { Chiefly medium-gray aphyric lava; } 10 \text { to } 20 \text { percent moderately olivine-phyric lava with } \\
\text { scattered clinopyroxene phenocrysts }\end{array}$ \\
\hline 524 & to & 504 & 1,340 & to & 1,360 & Medium-gray aphyric lava; 20 to 30 percent chips with small plagioclase phenocrysts \\
\hline 504 & to & 124 & 1,360 & to & 1,740 & $\begin{array}{l}\text { Medium-gray aphyric lava; } 5 \text { percent chips with plagioclase phenocrysts, } 10 \text { percent chips } \\
\text { with olivine and clinopyroxene phenocrysts }\end{array}$ \\
\hline 124 & to & -76 & 1,740 & to & 1,940 & gray silt-size matter \\
\hline
\end{tabular}

1 Rotary-drilling cuttings lifted with air, foam, and polymer. Sample repository: U.S. Geological Survey, Hawaii District office. 
The Waiohuli well penetrates a $1,940-\mathrm{ft}$ section of subaerial lava flows with interbedded tephra. The cuttings, generally fresh, range from massive to slightly vesicular basanite, hawaiite, and alkalic basalt. Specific compositions are not discernible in hand specimen but are based on chemical analyses from selected cuttings (table 3). Cuttings typically are medium gray in color, indicating that groundmass glass has not degraded extensively to clay minerals. Olivine phenocrysts range from oxidized to fresh, plagioclase is generally unaltered. Secondary mineralization is sparse to absent; opaline silica lightly coats some vesicle and fracture surfaces below 1,444-ft altitude. Tests using hydrochloric acid indicate almost no calcium carbonate as a secondary mineral.

Aphyric and slightly porphyritic lava predominate among the lava flows. Olivine-bearing lava, some moderately to highly porphyritic, forms less than 20 percent of the sequence. Clinopyroxene accompanies olivine as a phenocryst phase in some flows. Moderately plagioclase-bearing flows form less than 5 percent of the stratigraphic section penetrated by the drill stem. The porphyritic flows occur sporadically, never forming thick, homogeneous sequences as judged by their scant representation among cuttings from all depths.

Two discrete tephra sequences are presumed from cuttings collected at altitude intervals 1,379 to $1,324 \mathrm{ft}$ and 704 to $684 \mathrm{ft}$. Material from these intervals is entirely silt to sand in size. In contrast, chips are commonly as large as $1 \mathrm{in}$. from other depth intervals where lava flows presumably dominate the sequence. Thin individual tephra beds between lava flows would be impossible to recognize in the drill cuttings. One void is mentioned in the driller's notes between altitudes of 1,551 to $1,544 \mathrm{ft}$.

Medium-gray silt-sized cuttings were the only material returned from the 124- to -76-ft altitude interval, the bottom $200 \mathrm{ft}$ in the drill hole. It is unlikely that this extensive return of fine material represents $200 \mathrm{ft}$ of tephra accumulation. The material is not beach sand or other fluvial or marine sediment. The driller's log shows no change in drilling procedures. Conceivably, the sequence below the $124-\mathrm{ft}$ altitude comprises thin vesicular pahoehoe lava flows pulverized by drilling. This extensive return of fine material is otherwise unexplained.

Eight chemical analyses were obtained from cuttings at selected intervals (table 3 ). Rock chips were hand picked to obtain a petrographically uniform sample. However, the samples were composites and can not be shown to correspond to any single lava flow from the stratigraphic section. The sample collected from 524- to $514-\mathrm{ft}$ altitude is slightly porphyritic with small phenocrysts of plagioclase and olivine. Similar chips are sparse to lacking from cuttings immediately above and below those depths, so this sample may come closest to representing a single lava flow. The sample collected from 1,324- to 1,314-ft altitude is from coarse chips collected beneath a zone of silt-size cuttings (tephra?). These aphyric chips are larger than those from shallower parts of the hole and may therefore be from one or two flows at that depth. The boundary between the Kula Volcanics and the Honomanu Basalt is probably about $925 \mathrm{ft}$ deep in the Waiohuli drill hole, or about the 939-ft altitude, on the basis of the chemical analyses (David R. Sherrod, U.S. Geological Survey, Hawaiian Volcanoes Observatory, written commun., 2002).

\section{WATER-LEVEL AND WATER-QUALITY MEASUREMENTS}

Water-level measurements made in the Waiohuli exploratory well between September 2001 and April 2002 ranged from $5.58 \mathrm{ft}$ to $6.11 \mathrm{ft}$ above sea level (table 4). A water sample, collected from the well on April 3, 2002 , had a chloride concentration of $65.9 \mathrm{mg} / \mathrm{L}$. The specific conductance of the water sample was 442 $\mu \mathrm{S} / \mathrm{cm}$ and the temperature was $19.3^{\circ} \mathrm{C}$. The sample was collected from several feet below the water surface using a bailer attached to a steel cable on an electric reel. The water-level altitude, measured with a 2,000-ft graduated electric tape just prior to sampling, was $5.91 \mathrm{ft}$.

\section{SUMMARY}

The Waiohuli exploratory well (State well number 6-4421-01) is located on ranchland owned by the Department of Hawaiian Home Lands on the western slope of Haleakala. The well was constructed during April to August 2001 to study the hydrology and geology in an area where no other well information was available. The altitude of a brass plate embedded in the concrete pad at the well is $1,864.33$ feet above mean sea level and the well is 1,940 feet deep (bottom is at -76 feet altitude) and has a bore diameter of 7-7/8 in. A 1,924-ft solid steel casing with a 4-in. inner diameter 
Table 3. Chemical analysis of selected rock cuttings collected during drilling of the Waiohuli exploratory well (State well 6-4421-01), Maui, Hawaii

[Major- and trace-element data were determined by X-ray fluorescence methods using an automated Rigaku 3370 spectrometer at Washington State University (WSU) Geoanalytical Laboratories; accuracy and precision are discussed fully by Johnson and others (1999). Accuracy for major elements is better than 0.5 percent. For the trace elements, accuracy is better than 10 percent and commonly in the range 3 to 5 percent except for those elements in concentrations less than $10 \mathrm{ppm}$ (parts per million), in which case the precision may exceed 50 percent. Sc is only semiquantitative below the 30-ppm concentration. La and Ce concentrations are qualitative only. Major-element analyses normalized to 100 percent with all iron as $\mathrm{Fe}^{2+}$. Also shown are prenormalized oxide totals. Sample numbers indicate downhole depth, in feet. Altitude describes the range from which cuttings were gathered for each sample.]

\begin{tabular}{|c|c|c|c|c|c|c|c|c|}
\hline $\begin{array}{l}\text { Sample } \\
\text { number }\end{array}$ & WAIO-95 & WAIO-285 & WAIO-420 & WAIO-540 & WAIO-730 & WAIO-925 & WAIO-1180 & WAIO-1340 \\
\hline Altitude (ft) & $1,774-1,759$ & $1,579-1,569$ & $1,444-1,434$ & $1,324-1,314$ & $1,134-1,124$ & 939-919 & $684-669$ & $524-514$ \\
\hline Sample weight (g) & 12.5 & 14.4 & 17.5 & 17.5 & 15.4 & 11.1 & 16.5 & 13.4 \\
\hline Formation & $\begin{array}{c}\text { Kula } \\
\text { Volcanics }\end{array}$ & $\begin{array}{c}\text { Kula } \\
\text { Volcanics }\end{array}$ & $\begin{array}{c}\text { Kula } \\
\text { Volcanics }\end{array}$ & $\begin{array}{c}\text { Kula } \\
\text { Volcanics }\end{array}$ & $\begin{array}{c}\text { Kula } \\
\text { Volcanics }\end{array}$ & $\begin{array}{l}\text { Honomanu } \\
\text { Basalt }\end{array}$ & $\begin{array}{l}\text { Honomanu } \\
\text { Basalt }\end{array}$ & $\begin{array}{l}\text { Honomanu } \\
\text { Basalt }\end{array}$ \\
\hline Rock type & Hawaiite & Basanite & Hawaiite & Hawaiite & Hawaiite & Alkali basalt & Alkali basalt & Alkali basalt \\
\hline \multicolumn{9}{|c|}{ Major-element analyses, normalized water-free (weight percent) } \\
\hline $\mathrm{SiO}_{2}$ & 45.76 & 45.90 & 48.26 & 47.73 & 49.71 & 47.12 & 46.02 & 47.50 \\
\hline $\mathrm{Al}_{2} \mathrm{O}_{3}$ & 16.73 & 16.84 & 16.62 & 16.50 & 17.68 & 16.42 & 12.45 & 15.29 \\
\hline $\mathrm{TiO}_{2}$ & 3.85 & 3.89 & 3.75 & 3.70 & 3.52 & 3.33 & 3.221 & 4.10 \\
\hline $\mathrm{FeO}$ & 13.12 & 12.92 & 11.82 & 12.60 & 10.96 & 12.02 & 12.71 & 12.76 \\
\hline $\mathrm{MnO}$ & 0.220 & 0.218 & 0.242 & 0.237 & 0.243 & 0.174 & 0.171 & 0.18 \\
\hline $\mathrm{CaO}$ & 9.34 & 9.08 & 8.56 & 8.63 & 7.97 & 11.79 & 10.42 & 10.88 \\
\hline $\mathrm{MgO}$ & 5.09 & 5.01 & 4.56 & 4.53 & 3.28 & 5.06 & 11.85 & 5.080 \\
\hline $\mathrm{K}_{2} \mathrm{O}$ & 1.35 & 1.41 & 1.38 & 1.34 & 1.70 & 0.89 & 0.63 & 0.79 \\
\hline $\mathrm{Na}_{2} \mathrm{O}$ & 3.94 & 4.12 & 4.19 & 4.12 & 4.17 & 2.76 & 2.16 & 3.030 \\
\hline $\mathrm{P}_{2} \mathrm{O}_{5}$ & 0.61 & 0.61 & 0.61 & 0.61 & 0.76 & 0.446 & 0.359 & 0.40 \\
\hline Original oxide total & 98.75 & 99.20 & 99.69 & 99.28 & 98.70 & 99.43 & 99.46 & 99.63 \\
\hline \multicolumn{9}{|c|}{ Trace-element analyses (parts per million) } \\
\hline $\mathrm{Ni}$ & 2 & 6 & 0 & 2 & 0 & 66 & 328 & 51 \\
\hline $\mathrm{Cr}$ & 9 & 10 & 6 & 5 & 2 & 132 & 698 & 61 \\
\hline $\mathrm{Sc}$ & 14 & 11 & 18 & 11 & 13 & 18 & 31 & 27 \\
\hline $\mathrm{V}$ & 281 & 261 & 208 & 232 & 196 & 301 & 31 & 378 \\
\hline $\mathbf{B a}$ & 595 & 618 & 506 & 491 & 674 & 299 & 188 & 199 \\
\hline $\mathrm{Rb}$ & 28 & 29 & 28 & 26 & 34 & 16 & 11 & 12 \\
\hline $\mathrm{Sr}$ & 963 & 992 & 843 & 859 & 933 & 666 & 550 & 639 \\
\hline $\mathrm{Zr}$ & 235 & 241 & 273 & 273 & 306 & 232 & 172 & 213 \\
\hline$Y$ & 31 & 32 & 34 & 35 & 38 & 29 & 23 & 31 \\
\hline $\mathrm{Nb}$ & 51.1 & 51.3 & 49.6 & 48.5 & 61.7 & 30.6 & 19.2 & 22.6 \\
\hline $\mathrm{Ga}$ & 23 & 23 & 24 & 25 & 25 & 23 & 19 & 24 \\
\hline $\mathrm{Cu}$ & 5 & 7 & 0 & 0 & 0 & 67 & 48 & 65 \\
\hline $\mathrm{Zn}$ & 122 & 115 & 114 & 122 & 136 & 99 & 108 & 114 \\
\hline $\mathrm{Pb}$ & 1 & 3 & 0 & 3 & 5 & 2 & 0 & 3 \\
\hline $\mathrm{La}$ & 24 & 23 & 15 & 45 & 28 & 7 & 21 & 30 \\
\hline $\mathrm{Ce}$ & 74 & 71 & 86 & 74 & 91 & 46 & 55 & 29.0 \\
\hline Th & 2 & 5 & 4 & 3 & 4 & 1 & 3 & 3 \\
\hline
\end{tabular}


was installed and the bottom $90 \mathrm{ft}$ was hand perforated to create a well screen. The Waiohuli exploratory well penetrated a $1,940-\mathrm{ft}$ section of subaerial lava flows with interbedded tephra. On the basis of chemical analyses of eight samples of drill cuttings, the Honomanu Basalt/Kula Volcanics contact is placed at $939-\mathrm{ft}$ altitude.

Water-level measurements between September 2001 and April 2002 ranged from $5.58 \mathrm{ft}$ to $6.11 \mathrm{ft}$ above sea level. Water sampled from the well on April 3,2002 had a specific conductance of $442 \mu \mathrm{S} / \mathrm{cm}$, a temperature of $19.3^{\circ} \mathrm{C}$, and a chloride concentration of 65.9 $\mathrm{mg} / \mathrm{L}$.

Table 4. Water-level measurements from the Waiohuli exploratory well (State well 6-4421-01) Maui, Hawaii between September 2001 and August 2002

[Datum is mean sea level]

\begin{tabular}{lc}
\hline Date and time & $\begin{array}{c}\text { Water level } \\
\text { (feet) }\end{array}$ \\
\hline September 27, 2001; 14:09 & 5.58 \\
December 18, 2001; 11:10 & 6.11 \\
February 14, 2002; 13:20 & 6.05 \\
April 3, 2002;11:25 & 5.91 \\
June 18, 2002;11:20 & 5.71 \\
August 22, 2002;11:30 & 5.73 \\
\hline
\end{tabular}

\section{REFERENCES CITED}

Johnson, D.M., Hooper, P.R., and Conrey, R.M., 1999, XRF analysis of rocks and minerals for major and trace elements on a single low dilution Li-tetraborate fused bead: Advances in X-ray Analysis, v. 41, p. 843-867.

Langenheim, V.A.M., and Clague, D.A., 1987, The Hawaiian-Emperor volcanic chain: stratigraphic framework of volcanic rocks of the Hawaiian islands, chap. 1 of Decker, R.W., Wright, T.L., and Stauffer, P.H., eds., Volcanism in Hawaii: U.S. Geological Survey Professional Paper 1350, v. 1, p. 55-84.

Stearns, H.T., and Macdonald, G.A., 1942, Geology and ground-water resources of the island of Maui, Hawaii: Territory of Hawaii, Division of Hydrography Bulletin 7, $344 \mathrm{p}$. 